\title{
A reversible severe gait disorder
}

回

\section{Supplemental data} at Neurology.org
A 53-year-old man was admitted for a 6-month progressive disabling gait disorder, weight loss, and increasing fatigue. Examination revealed a markedly impaired gait and flexion contractures of hips and knees, with limited extension (video 1 at Neurology.org). EMG and whole neuraxis MRI were normal. Laboratory workup proved primary adrenal insufficiency (AI) (serum cortisol $2.4 \mu \mathrm{g} / \mathrm{dL}$, ACTH $513.8 \mathrm{pg} / \mathrm{mL}$ ). Flexion contractures of the lower limbs $s^{1,2}$ (FCLL) due to AI was suspected. Prompt treatment with hydrocortisone supplementation led to a substantial clinical improvement (video 2). FCLL is a well-known but infrequent sign of AI. Prompt identification and treatment may reverse this disorder.

Gustavo Zapata-Wainberg, MD, Rocio López Ruiz, MD, Elena Fernández González, MD Pilar Alcántara Miranda, MD, Mercedes Gallego, MD, Ana María Ramos-Levi, MD, José Vivancos, MD, PhD

From the Neurology Department (G.Z.-W., R.L.R., P.A.M., M.G., J.V.) and Endocrinology Department (E.F.G., A.M.R.-L.) Hospital Universitario de La Princesa, Madrid. Instituto de Investigación Sanitaria La Princesa.

Author contributions: Gustavo Zapata-Wainberg: study concept and design, acquisition, analysis and interpretation of data. Rocío López Ruiz: acquisition of data, revision of manuscript. Elena Fernández González: acquisition of data, revision of manuscript. Pilar Alcántara Miranda: acquisition of data, revision of manuscript. Mercedes Gallego: acquisition of data, revision of manuscript. Ana María RamosLevi: acquisition and analysis of data, revision of manuscript, study supervision. José Vivancos: analysis and interpretation of data, revision of manuscript, study supervision.

Study funding: No targeted funding reported.

Disclosure: The authors report no disclosures relevant to the manuscript. Go to Neurology.org for full disclosures.

Correspondence to Dr. Zapata-Wainberg: gzapatawainberg@gmail.com

1. Nishikawa T. Flexion contractures possibly reflect the existence of hypocortisolism. Intern Med 2003;42:629-631.

2. Harbuz V, Bihan H, Salama J, Reach G, Cohen R. Flexion contractures possibly reflect the existence of hypocortisolism: two case reports. J Neurol 2010;257:1129-1133.

\section{WriteClick ${ }^{\circledR}$ rapid online correspondence}

The editors encourage comments about recent articles through WriteClick:

Go to Neurology.org and click on the "WriteClick" tab at the top of the page. Responses will be posted within 72 hours of submission.

Before using WriteClick, remember the following:

- WriteClick is restricted to comments about studies published in Neurology within the last eight weeks

- Read previously posted comments; redundant comments will not be posted

- Your submission must be 200 words or less and have a maximum of five references; reference one must be the article on which you are commenting

- You can include a maximum of five authors (including yourself) 


\section{Neurology}

A reversible severe gait disorder

Gustavo Zapata-Wainberg, Rocío López Ruiz, Elena Fernández González, et al.

Neurology 2016;87;1521

DOI 10.1212/WNL.0000000000003190

This information is current as of October 3, 2016

$\begin{array}{ll}\begin{array}{l}\text { Updated Information \& } \\ \text { Services }\end{array} & \begin{array}{l}\text { including high resolution figures, can be found at: } \\ \text { http://n.neurology.org/content/87/14/1521.full }\end{array} \\ \text { Supplementary Material } & \begin{array}{l}\text { Supplementary material can be found at: } \\ \text { http://n.neurology.org/content/suppl/2016/10/03/WNL.0000000000003 } \\ 190 . D C 1\end{array} \\ & \text { This article cites } 2 \text { articles, } 0 \text { of which you can access for free at: } \\ & \text { http://n.neurology.org/content/87/14/1521.full\#ref-list-1 } \\ \text { References } & \text { This article, along with others on similar topics, appears in the } \\ \text { following collection(s): } \\ \text { Endocrine } \\ \text { http://n.neurology.org/cgi/collection/endocrine } \\ \text { Gait disorders/ataxia } \\ \text { http://n.neurology.org/cgi/collection/gait_disorders_ataxia } \\ \text { Neuroendocrinology } \\ \text { http://n.neurology.org/cgi/collection/neuroendocrinology } \\ \text { Information about reproducing this article in parts (figures,tables) or in } \\ \text { its entirety can be found online at: } \\ \text { http://www.neurology.org/about/about_the_journal\#permissions } \\ \text { Information about ordering reprints can be found online: } \\ \text { http://n.neurology.org/subscribers/advertise }\end{array}$

Neurology ${ }^{\circledR}$ is the official journal of the American Academy of Neurology. Published continuously since 1951, it is now a weekly with 48 issues per year. Copyright @ 2016 American Academy of Neurology. All rights reserved. Print ISSN: 0028-3878. Online ISSN: 1526-632X.

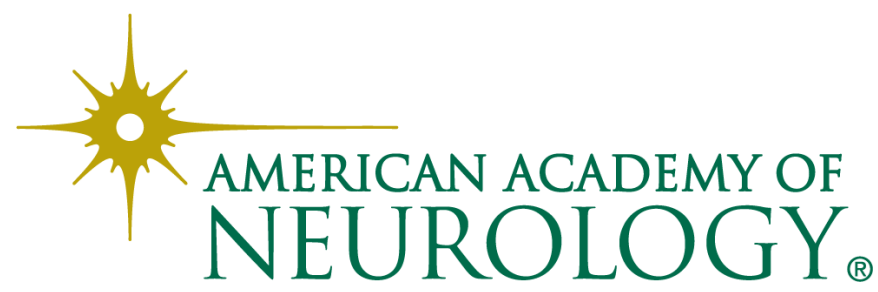

